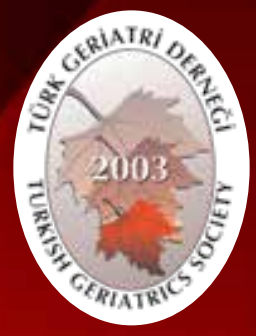

Turkish Journal of Geriatrics DOI: 10.31086/tjgeri.2019.90 2019;22 (2):172-180

\section{- Cihangir DOĞU² iD - Selçuk KAYIR ${ }^{1}$ iD - Güvenç DOĞAN ${ }^{1}$ - Arzu EKICI AKDAĞLI' 1 iD - Serhat ÖZÇIFTÇi ${ }^{1}$ (D) • Özgür YAĞAN ${ }^{1}$}

\title{
TRACHEOTOMY AMONG PATIENTS IN GERIATRIC AGE GROUP TREATED IN INTENSIVE CARE UNITS
}

\section{Abstract}

Introduction: In intensive care units, numerous geriatric patients are mechanically ventilated, and those with prolonged mechanical ventilation show high mortality. Such geriatric patients may greatly benefit from tracheotomy because it facilitates pulmonary care, increases patient comfort and helps wean them off mechanical ventilation.

Materials and Method: A total of 70 mechanically ventilated geriatric patients were includ-ed. Patients' electronic data, file records, age, sex, mechanical ventilation requirement, Acute Physiology and Chronic Health Evaluation II score, intubation and intensive care unit stay durations, discharge status and complications were examined.

Results: The mean patient age was 78.6 \pm 7.4 years, and the mean Acute Physiology and Chronic Health Evaluation II score was 27.0 \pm 5.9. Tracheotomy was performed after a mean duration of $34.8 \pm 17$ days, and the mean intensive care unit stay duration was $94 \pm 54$ days. Major and minor haemorrhage were observed in $1(1.4 \%)$ and $3(4.2 \%)$ patients, respectively. Total $53(76 \%)$ patients died, $8(11 \%)$ patients were discharged and $9(13 \%)$ patients are still hospitalized.

Conclusion: The reluctance of geriatric patients' relatives to perform tracheotomy affects the time of procedure and duration of intensive care unit stay.

Keywords: Critical care; Geriatrics; Tracheotomy; Respiration, Artificial

ARAŞTIRMA

CORRESPONDANCE

Selçuk KAYIR

Hitit University, Erol Olçok Training and Research Hospital, Department of Anesthesiology and Reanimation, Çorum, Turkey

Phone: +903642193000

e-mail: drskayir@gmail.com

Received: 07/01/2019

Accepted: $20 / 05 / 2019$

Hitit University, Erol Olçok Training and Research Hospital, Department of Anesthesiology and Reanimation, Çorum, Turkey.

2 Hitit University, Erol Olçok Training and Research Hospital, Department of Critical Care, Çorum, Turkey.

\section{YOĞUN BAKIMDA TAKIP EDILEN GERIATRI YAŞ GRUBU HASTALARDA TRAKEOTOMI}

$\ddot{O}_{z}$

Giriş: Yoğun bakım ünitelerinde, çok sayıda geriatri hastalarının mekanik ventilasyona bağlanmaktadır. Uzun süreli mekanik ventilasyonu bağlı hastalar yüksek mortalite göstermektedir. Bu geriatri yaş grubu hastalar, trakeotomiden büyük ölçüde faydalanabilir çünkü trakeotomi akciğer bakımını kolaylaştııı, hasta konforunu arttıır ve mekanik ventilasyondan kurtulmalarına yardımcı olur.

Gereç ve Yöntem: Çalışmada mekanik ventilasyona bağlı toplam 70 geriatri yaş grubunda hasta alındı. Hastaların elektronik verileri, dosya kayıtları, yaş, cinsiyet, mekanik ventilasyon gereksinimi, Akut Fizyoloji ve Kronik Sağlık Değerlendirmesi II skoru, entübasyon ve yoğun bakım ünitesinde kalma süresi, taburculuk durumu ve komplikasyonları incelendi.

Bulgular: Ortalama hasta yaşı $78.6 \pm 7.4$ yıl ve ortalama Akut Fizyoloji ve Kronik Sağlık Değerlendirmesi II skoru 27.0 \pm 5.9 idi. Ortalama $34.8 \pm 17$ gün sonra trakeotomi yapıldı ve yoğun bakımda kalıs süresi ortalama $94 \pm 54$ gündü. Hastaların 1'inde majör (\%1.4), üçünde (\%4.2) minör kanama izlendi. Toplam 53 (\%76) hasta öldü, 8 (\%11) hasta taburcu edildi ve $9(\% 13)$ hasta hala hastanede kaldı.

Sonuç: Geriatri yaş grubundaki hastaların yakınlarının trakeotomi yapma konusundaki isteksizliği, işlem süresini ve yoğun bakım ünitesinde kalma süresini etkilemektedir.

Anahtar sözcükler: Yoğun bakım; Geriatri; Trakeotomi; Yapay solunum 


\section{INTRODUCTION}

Compared with intubation, tracheotomy provides better alveolar ventilation in patients requir-ing prolonged mechanical ventilation (1). Tracheotomy also facilitates pulmonary care, reduces dead space and airway resistance, increases patient comfort and helps wean patients off me-chanical ventilation. Tracheotomy is recommended in patients with respiratory failure who cannot tolerate extubation within 7-14 days (2). Percutaneous dilatational tracheotomy (PDT) confers a lower risk of wound infection than surgical tracheotomy and prevents risks associat-ed with the transportation of patients because it can be performed at the bedside. Currently, PDT has replaced surgical tracheostomy for patients treated in intensive care units (ICUs) (3).

The number of geriatric patients admitted to ICUs has considerably increased owing to the ageing population (4). Previous studies have shown that it is difficult to wean geriatric pa-tients off mechanical ventilators (5) and that they often die even before being discharged from the hospital (6). Reduced lung elasticity, weakened respiratory muscles and decreased lung capacity in geriatric patients render the weaning of mechanical ventilation difficult (7). Moreover, high mortality has been reported in geriatric patients requiring prolonged mechanical ventilation (8). Thus, many elderly patients may greatly benefit from tracheotomy. Longterm intubation should not be the only criterion for the indication of tracheotomy, and the need for tracheotomy in critically ill patients should be reviewed (2). In the present study, we aimed to retrospectively examine events of late tracheotomy in geriatric patients treated in ICU at a provincial education and research hospital.

\section{MATERIALS AND METHOD}

Patients aged $>65$ years who were treated with PDT between January 2015 and October 2018 were included in the study. This study was approved by the Ethics Committee of Hitit Uni-versity (2018-212) and was conducted in accordance with the World
Medical Association Declaration of Helsinki. The patients' data records and follow-up forms were examined. Patients aged $<65$ years and those with missing data records or follow-up forms were excluded from the study.

Percutaneous dilatational tracheotomy indications considered at our clinic include prolonged mechanical ventilation, weaning failure, need for mechanical ventilation, presence of neurological disease, upper respiratory tract stenosis and frequent bronchial cleansing. PDT was never performed in the absence of family and/or patient consent, presence of bleeding diathesis (platelet count $<60,000 \mathrm{~mm}^{3} / \mathrm{L}$; international normalised ratio $>1.5$ ), requirement of high oxygenation support (positive end-expiratory pressure $>10 \mathrm{mmHg}_{1} \mathrm{FiO}_{2}>$ $80 \%$ ) and presence of cervical trauma.

At our clinic, PDT is performed following the standard Griggs forceps technique using supraglottic airway devices with appropriate anesthesia induction. After each procedure, the suc-cess of tracheotomy is evaluated via clinical observation and postero-anterior chest radiog-raphy.

Patients' electronic data, file records, age, sex, mechanical ventilation-requiring diagnosis, Acute Physiology and Chronic Health Evaluation (APACHE) II score, intubation and ICU stay duration, discharge status (healthy, sequelae or mechanical ventilation) and complications (bleeding, subcutaneous emphysema, false pneumothorax passage, hypotension, hypoxia, tra-cheal injury or mortality) were recorded.

\section{Statistical analyses}

Data were analyzed using Statistical Package for the Social Sciences software for Windows (version 22.0; SPSS Inc., Chicago, IL, United States). Whether continuous variables were normally distributed was determined using the Kolmogorov-Smirnov test. Levene's test was used for evaluating variance homogeneity. Continuous data were presented as mean \pm standard deviation (sd); median (range) was used for skewed distributions. Categorical data were pre-sented as number of cases (\%). 
Differences in non-normally distributed variables between two independent groups were as-sessed using the Mann-Whitney U-test and those among more than two independent groups were assessed using the Kruskal-Wallis test. When the p-values from the Kruskal-Wallis test results were statistically significant, the post-hoc Conover-Iman test of multiple comparisons was used to assess which group differs from which others.
Degrees of relation between variables were evaluated using Spearman's correlation test. $p<0.05$ was considered statistically significant.

\section{RESULTS}

Data of total 85 patients who underwent PDT were analysed; after excluding 12 and 3 of those owing to age $<65$ years and missing data records, respectively, a total of 70 patients [33 (47\%) males and 37 (53\%)

Table 1. Demographic and other features.

\begin{tabular}{|c|c|c|}
\hline Variable & $n$ & $\%$ \\
\hline \multicolumn{3}{|l|}{ Gender } \\
\hline Male & 33 & 47.1 \\
\hline Female & 37 & 52.9 \\
\hline \multicolumn{3}{|l|}{ Age } \\
\hline 65 to 79 & 38 & 54.3 \\
\hline 80 and above & 32 & 45.7 \\
\hline \multicolumn{3}{|l|}{ Diagnosis } \\
\hline Hypoxic encephalopathy & 9 & 12.9 \\
\hline $\begin{array}{l}\text { Chronic Obstructive Pulmonary } \\
\text { Disease }\end{array}$ & 14 & 20.0 \\
\hline Carcinomas & 2 & 2.9 \\
\hline Stroke & 18 & 25.7 \\
\hline Intracranial Hemorrage & 8 & 11.4 \\
\hline Type-I Pulmonary Disease & 18 & 25.7 \\
\hline Pulmonary Fibrosis & 1 & 1.4 \\
\hline \multicolumn{3}{|l|}{ Discharge status } \\
\hline Discharged & 8 & 11.4 \\
\hline Still in the service & 9 & 12.9 \\
\hline Exitus & 53 & 75.7 \\
\hline \multicolumn{3}{|l|}{ Complication } \\
\hline Arrhythmia & 1 & 1.4 \\
\hline Bleeding & 3 & 4.3 \\
\hline No & 66 & 94.3 \\
\hline
\end{tabular}


females] were finally included. The mean patient age was $78.6 \pm 7.4$ years, and the mean APACHE II score was $27 \pm 5.9$, indication day was $13.54 \pm 5.12$, consent day was $30.94 \pm 16.37$ days. Tracheotomy was performed after a mean duration of $34.8 \pm 17.6$ days, and the mean ICU stay duration was $94 \pm 54$ days. Indications for mechanical ventilation are summarized in Table 1.

Consent for tracheotomy was obtained from 7 of the patients' relatives before the 15th day of mechanical ventilation, and no tracheotomy was performed during that time. Results of the evaluation of the tracheotomy indication duration, time of obtaining consent and opening time according to follow-up and discharge groups are presented under Table 2. Table 3 presents a comparison of the patient groups aged $65-79$ and $>80$ years. Table 4 presents results of the correlation analysis for the day of indication, approval and procedure; the results revealed a significant positive correlation between the duration of the procedure and the duration of ap-proval (high degree), indication (moderate) and admission day (moderate) $(p<0.05)$. A posi-tive correlation was also observed between the duration of approval and indication (moderate; $\mathrm{p}<0.05$ ).

Minor and major haemorrhage were noted in 3 (4.2\%) and 1 (1.4\%) patient, respectively, and tracheotomy cannula could not be established in 1 (1.4\%) patient. Moreover, 54 (76\%) pa-tients died during the study period; 8 (11\%) were discharged and $9(13 \%)$ are still hospital-ised.

\section{DISCUSSION}

We investigated the usefulness of PDT in geriatric patients treated in ICUs. In our patient cohort, tracheotomy was performed after a mean duration of 35 days, and the mean ICU stay duration was approximately 95 days. Various opinions have been reported regarding the tra-cheotomy opening time and benefits in patients treated in ICUs. A metaanalysis reported that tracheotomy procedures performed before the $10^{\text {th }}$ day of mechanical ventilation had shorter ventilation duration, ICU stay duration and lower long-term mortality compared with proce-dures performed later than that (9).

Table 2. Evaluation of the patient groups.

\begin{tabular}{|c|c|c|c|c|}
\hline \multirow{2}{*}{ Variable } & \multicolumn{3}{|c|}{$\begin{array}{c}\text { Meantsd } \\
\text { Median (min-max) }\end{array}$} & \multirow{2}{*}{$\mathbf{p}$} \\
\hline & Discharged & In the Service & Exitus & \\
\hline APACHE II & $\begin{array}{r}26.50 \pm 1.69 \\
26.5(24-29)\end{array}$ & $\begin{array}{r}26.00 \pm 6.32 \\
27(16-35)\end{array}$ & $\begin{array}{r}27.25 \pm 6.37 \\
26(12-46)\end{array}$ & 0.922 \\
\hline Procedure day & $\begin{array}{l}32.88 \pm 13.77 \\
29.5(16-58)\end{array}$ & $\begin{array}{r}48.67 \pm 21.28 \\
39(32-100) \\
\end{array}$ & $\begin{array}{r}32.74 \pm 16.73 \\
28(8-94) \\
\end{array}$ & $0.024^{c}$ \\
\hline Consent day & $\begin{array}{r}30.50 \pm 14.54 \\
27(10-55)\end{array}$ & $\begin{array}{r}45.56 \pm 20.21 \\
36(30-93)\end{array}$ & $\begin{array}{r}28.53 \pm 14.87 \\
25(6-85)\end{array}$ & $0.014^{c}$ \\
\hline Indication day & $\begin{array}{r}12.75 \pm 2.71 \\
14(7-15) \\
\end{array}$ & $\begin{array}{r}18.89 \pm 7.83 \\
18(10-35) \\
\end{array}$ & $\begin{array}{r}12.75 \pm 4.32 \\
12(5-25) \\
\end{array}$ & $0.035^{c}$ \\
\hline Length of stay & $\begin{array}{r}73.75 \pm 31.59 \\
72(34-125)\end{array}$ & 111 & $\begin{array}{r}94.06 \pm 59.63 \\
81(15-285)\end{array}$ & 0.626 \\
\hline
\end{tabular}

Continuous variables were compared with the Kruskal-Wallis test. Conover-Inman test were performed for the binary comparisons among the groups and the $p$ value was set at 0.05. Sig-nificant differences were found between: $a$, discharged vs in the service; $b$, discharged vs Exi-tus; $c$, in the service vs Exitus. 
Turković et al. compared early and late tracheotomy and reported that the mechanical ventila-tion and ICU stay durations were shorter in patients who underwent early tracheotomy; however, they emphasized that tracheotomy did not affect the overall hospital stay duration (10). In their study involving 78 geriatric patients, Baskin et al. reported that those with respiratory failure were difficult to be weaned off the mechanical ventilator after tracheotomy. They also reported that those patients never recovered their swallowing ability, had to be fed via a gas-trostomy tube, that their vocal cord functions did not return and that they could not gain from the potential benefits of tracheotomy. They also reported that poorly diseased geriatric patients with respiratory insufficiency exhibited poor outcomes after tracheostomy, thereby sug-gesting that clinicians should assess which population would be appropriate for tracheotomy (2). Considering the opinions of patients and their relatives, an editorial article countering this research (11) reported that patients with very serious disease may benefit from a second visit. The prognosis of patients and their expectation of quality of life after discharge should be evaluated during patient visits. Freeman et al. performed tracheotomy in 2472 patients who received 43,000 ventilation supports; the mean time to tracheotomy was 10 days, the mean hospital stay duration was 37 days and the mean ICU stay duration was 17 days. The authors also emphasized the fact that more than one extubation trial was performed in their patients undergoing tracheotomy and that tracheotomy was perceived differently in rural areas and metropolises. In addition, mortality was lower in patients who underwent tracheotomy, and intensive care physicians desired to perform tracheotomy in patients who could be discharged from ICUs (12).

In the present study, tracheotomy was performed after a mean duration of 35 days and was reported as late tracheotomy in the literature. In our clinic, the most common indication of tracheotomy is unsuccessful weaning as stated in the literature, and in the case of intubation longer than 10 days, patients and their relatives are requested for consent for performing tra-cheotomy. When the evaluation was conducted according to age groups, the duration of indi-cation was 12 and 14 days for patients aged $65-79$ and $>80$ years, respectively.

Table 3. Evaluation of the patient groups.

\begin{tabular}{|c|c|c|c|}
\hline \multirow{2}{*}{ Variable } & \multicolumn{2}{|c|}{$\begin{array}{c}\text { Mean } \pm \text { sd } \\
\text { Median (min-max) }\end{array}$} & \multirow{2}{*}{$\mathbf{p}$} \\
\hline & $65-79$ years of age & $65-79$ years of age & \\
\hline APACHE II & $\begin{array}{l}27.26 \pm 5.03 \\
26(18-40)\end{array}$ & $\begin{array}{r}26.69 \pm 7.00 \\
26(12-46) \\
\end{array}$ & 0.562 \\
\hline Procedure day & $\begin{array}{r}33.50 \pm 17.09 \\
29(8-100) \\
\end{array}$ & $\begin{array}{r}36.34 \pm 18.45 \\
31.5(14-94) \\
\end{array}$ & 0.520 \\
\hline Consent day & $\begin{array}{r}30.63 \pm 16.63 \\
27.5(6-93) \\
\end{array}$ & $\begin{array}{r}31.31 \pm 16.31 \\
29(7-85) \\
\end{array}$ & 0.869 \\
\hline Indication day & $\begin{array}{r}12.66 \pm 5.07 \\
12(5-35) \\
\end{array}$ & $\begin{array}{r}14.59 \pm 5.06 \\
14(7-25) \\
\end{array}$ & 0.083 \\
\hline Length of stay & $\begin{array}{r}86.88 \pm 52.57 \\
80(15-190)\end{array}$ & $\begin{array}{r}96.97 \pm 61.05 \\
84(28-285)\end{array}$ & 0.410 \\
\hline
\end{tabular}

Continuous variables are expressed as either the mean \pm standard deviation (sd) or median (minimum-maximum).

Continuous variables were compared using the Mann-Whitney U-test. 
Table 4. Evaluation of the patient groups.

\begin{tabular}{|c|c|c|c|c|c|c|}
\hline & & Age & APACHE II & $\begin{array}{r}\text { Procedure } \\
\text { day }\end{array}$ & $\begin{array}{r}\text { Consent } \\
\text { day }\end{array}$ & $\begin{array}{r}\text { Indication } \\
\text { day }\end{array}$ \\
\hline \multirow{3}{*}{ Age } & $r$ & 1.000 & -0.005 & 0.064 & 0.029 & 0.151 \\
\hline & $\mathrm{p}$ & . & 0.970 & 0.597 & 0.812 & 0.211 \\
\hline & $n$ & 70 & 70 & 70 & 70 & 70 \\
\hline \multirow{3}{*}{ Apache II } & $r$ & & 1.000 & 0.027 & 0.045 & 0.014 \\
\hline & $p$ & & & 0.825 & 0.714 & 0.910 \\
\hline & $\mathrm{n}$ & & 70 & 70 & 70 & 70 \\
\hline \multirow{3}{*}{$\begin{array}{l}\text { Procedure } \\
\text { day }\end{array}$} & $r$ & & & 1.000 & 0.970 & 0.554 \\
\hline & $p$ & & & . & $<0.001$ & $<0.001$ \\
\hline & $n$ & & & 70 & 70 & 70 \\
\hline \multirow{3}{*}{$\begin{array}{l}\text { Consent } \\
\text { day }\end{array}$} & $r$ & & & & 1.000 & 0.514 \\
\hline & $p$ & & & & . & $<0.001$ \\
\hline & $n$ & & & & 70 & 70 \\
\hline \multirow{3}{*}{$\begin{array}{l}\text { Indication } \\
\text { day }\end{array}$} & $r$ & & & & & 1.000 \\
\hline & $\mathrm{p}$ & & & & & \\
\hline & $n$ & & & & & 70 \\
\hline
\end{tabular}

Tracheotomy was not performed before the 15th day of mechanical ventilation. Consent for tracheotomy was obtained from the relatives of only seven patients, the durations to which were found to be 30.63 days and 31.31 days for patients aged 65-79 and $>80$ years, respectively. The dura-tions of the procedure following approval were 33.5 and 36.5 days for patients aged $65-79$ and $>80$ years, respectively. A correlation was observed between the day of approval and the day of the procedure. Once tracheotomy was approved, the procedure was performed at the best time in our clinic. We think that the tracheotomies were performed in late period particularly in geriatric patients because of their low discharge expectancy by the relatives and be-cause the approval of the procedure was delayed. We also assume that, in accordance with the literature, the hospitalization duration depends on the delayed tracheotomy time (13).

The duration of tracheotomy was significantly shorter in patients who were discharged than in those who were followed up in the service and died. Patients who were still being followed up in the service were newly diagnosed respiratory failure patients. The tracheotomy indication for patients who underwent a weaning trial was relatively late. We have performed more than one weaning trials, the results of which are consistent with the study of Freeman et al. (12). However, we found that patients who were followed up in the service had a longer tra-cheotomy time than those who died. This is the result of our study against the literature. 
Figure 1. Correlation between the time of approval and tracheotomy time.

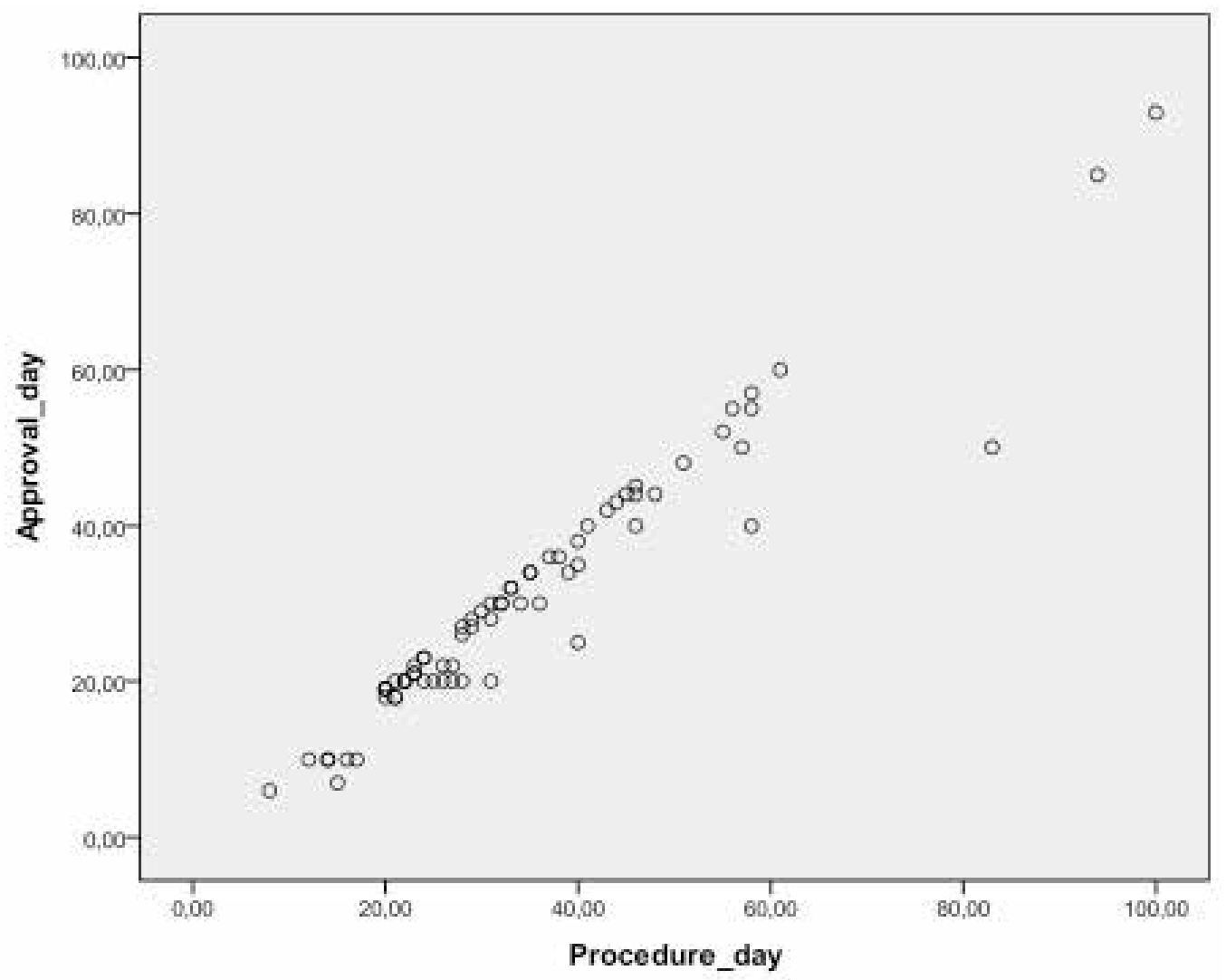

Duran et al. examined 47 tracheotomy patients in a geographically western metropolitan area; their reported mean patient age was similar to that in our study. However, in their study, the average number of days to tracheotomy was 10.9 (14). Reason for the longer time to tracheot-omy in our patients compared with that in Duran et al.'s study can be the fact that in rural settings, similar to the one in our study, relatives do not expect geriatric patients to survive longer and are hesitant to approve a surgical procedure.

The mean ICU stay duration in our patients was approximately 94 days. The mean ICU stay duration was 37 days as per Freeman et al. (12), 30 days (15) as per Kollef et al. and 34 days as per Duran et al. (14). In the present study, ICU stay duration was considerably longer than that reported in the literature perhaps due to the fact that the patients' relatives were reluctant to accept the care of patients undergoing tracheotomy despite them being suitable for dis-charge. In our region, no palliative care centre has yet been established to treat such patients, and this has resulted in prolonged hospitalization durations and increased hospital mortalities. Therefore, the frequency of discharge to the palliative care service in our hospital was only $11 \%$.

Haemorrhage, which was reported in 5.6\% of the patients, was the most common complica-tion encountered in our study. A meta-analysis conducted by Delaney et al. reported that the average rate of haemorrhage across 10 randomized controlled 
trials was $5.7 \%$. Moreover, PDT was not associated with a higher risk of haemorrhage than was surgery (3). Cormick and Manara presented cases of three patients who died from innominate vein injury during PDT and recommended evaluating venous structures using ultrasonography (USG) before the pro-cedure. Moreover, they reported that the use of fibreoptic bronchoscopy during the procedure would help confirm the location of cannula (16). A meta-analysis conducted by Sanabria re-ported no differences between surgical and percutaneous techniques. The Ciaglia Blue Rhino method may be suitable for minor haemorrhages; however, the clinical experience and opera-tor skill required are critical (17). In the present study, no patient was lost to haemorrhage. Major haemorrhage occurred due to venous bleeding and was resolved via little bedside inter-vention using general surgery. We believe that venous structures should be evaluated using USG before the procedure. Moreover, anatomical

\section{REFERENCES}

1. Mallick A, Bodenham AR. Tracheostomy in critically ill patients. Eur J Anaesthesiol 2010;27(8):676-82. (PMID:20523214).

2. Baskin JZ, Panagopoulos G, Parks C, Rothstein S, Komisar A. Clinical outcomes for the elderly patient receiving a tracheotomy. Head Neck 2004;26(1):71-76. (PMID:14724909).

3. Delaney A, Bagshaw SM, Nalos M. Percutaneous dilatational tracheostomy versus surgical tracheostomy in critically ill patients: a systematic review and meta-analysis. Crit Care 2006;10(2):R55. (PMID:16606435)

4. Turan G, Yildirim AR A, Kuplay YY, Abitağaoğlu S, Şanlı Karip C, Öksüz M. Weaning in geriatric patients: a retrospective clinical study. Turk J Geriatr 2017;20(4):264-70.

5. Engoren M, Arslanian-Engoren C, Fenn-Buderer N. Hospital and long-term outcome after tracheostomy for respiratory failure. Chest 2004;125(1):220-27. (PMID:14718444)

6. Dewar DM, Kurek CJ, Lambrinos J, Cohen IL, Zhong Y. Patterns in costs and out-comes for patients with prolonged mechanical ventilation undergoing variations may develop in geriatric patients due to fibrosis, ageing and decreased connective tissue volume; however, these complications can be avoided with adequate preoperative evaluation.

The tracheotomy cannula of one patient was not appropriately located, and re-intubation was performed due to lack of ventilation; the tracheotomy stoma was closed, and the patient was followed up with intubation. A false route may occur when the cannula opens at an incorrect location during the procedure. After a successful procedure, the tracheotomy cannula may be displaced during patient care or mobilization (18). An approximately $1 \%$ incidence rate of false route cannulation after PDT has been reported (12), which is consistent with our find-ings.

In conclusion, PDT is safe for geriatric patients. However, the reluctance of geriatric patients' relatives to perform tracheotomy affects the time of the procedure and the duration of ICU stay.

tracheostomy: an analysis of discharges under diagnosis-related group 483 in New York State from 1992 to 1996. Crit Care Med 1999;27(12):2640-47. (PMID:10628603).

7. Cader SA, de Vale RG, Castro JC, et al. Inspiratory muscle training improves maximal inspiratory pressure and may assist weaning in older intubated patients: a randomised trial. J Physiother 2010;56(3):171-7. (PMID:20795923).

8. Lai CC, Ko SC, Chen CM, Weng SF, Tseng KL, Cheng $\mathrm{KC}$. The outcomes and prog-nostic factors of the very elderly requiring prolonged mechanical ventilation in a single respiratory care centre. Medicine (Baltimore) 2016;95(2):e2479. (PMID:26765452)

9. Hosokawa K, Nishimura M, Egi M, Vincent JV. Timing of tracheotomy in ICU pa-tients: a systematic review of randomized controlled trials; Critical Care 2015;19:424. (PMID:26635016).

10. Turković TM, Lukić A, Perić M. Early versus late percutaneous tracheotomy in critical-ly ill patients: $A$ retrospective single center observational study. Acta Clin Croat 2016;55(1):33-40. (PMID:27276770).

11. Norton SA, Quill TE. Complex questions embedded 
in tracheotomy decisions; Head Neck 2004;26(1):7576. (PMID:14738090).

12. Freeman BD, Borecki IB, Coopersmith CM, Buchman TG. Relationship between tracheostomy timing and duration of mechanical ventilation in critically ill patients. Crit Care Med 2005;33(11):2513-20. (PMID:16276175).

13. Schneider GT, Christensen N, Doerr TD. Early tracheotomy in elderly patients results in less ventilator-associated pneumonia; Otolaryngol Head Neck Surg 2009;140(2)250-55. (PMID:19201298).

14. Duran FY, Albayrak D. Percutaneous tracheostomy application to geriatric patients in an intensive care unit by anesthesiologists: an analysis of 47 cases. Cyprus J Med Sci 2016;1:1-4.
15. Kollef MH, Ahrens TS, Shannon W. Clinical predictors and outcomes for patients re-quiring tracheostomy in the intensive care unit. Crit Care Med 1999;27(9):171420. (PMID:10507588).

16. McCormick B, Manara AR. Mortality from percutaneous dilatational tracheostomy. A report of three cases. Anaesthesia 2005;60(5):490-95. (PMID:15819770).

17. Sanabria A. Which percutaneous tracheostomy method is better? A systematic review. Respir Care 2014;59(11):1660-70. (PMID:25185145).

18. Fernandez-Bussy S, Mahajan B, Folch E, Caviedes I, Guerrero J, Majid A. Tracheostomy tube placement early and late complications. J Bronchol Intervent Pulmonol 2015;22(4):357-64. (PMID:26348694). 